\title{
Globe luxation following cow horn injury
}

\author{
Deepsekhar Das, ${ }^{\circledR}$ Ranjitha Gowdar Kuberappa, Suman Kumari Meena, Rachna Meel
}

Dr. R. P. Centre for Ophthalmic Sciences, All India Institute of Medical Sciences, New Delhi, India

\section{Correspondence to Dr Deepsekhar Das, doc.deep.das@gmail.com}

Accepted 3 April 2019

\section{DESCRIPTION}

A 24-year-old man presented to the casualty at AIIMS with history of injury to his left eye following an accident when he happened to hit a cow, followed by sudden loss of vision, pain and bleeding from the left eye.

On examination, his left globe was found to be displaced anteriorly out of the orbit. Visual acuity was no light perception. Both upper and lower lids were mildly chemosed and located behind the luxated globe.(figure 1) There was also an extensive laceration involving the medial canthus. Irregular laceration of the conjunctiva and tenon's was noted. Cornea was hazy and edematous, rest of the intraocular details could not be visualised clearly. Sclera was exposed with multiple haemorrhagic spots. Lateral rectus insertion was found to be intact. Avulsion of optic nerve was noted and cut end, measuring approximately 1.5 to $2 \mathrm{~cm}$, was lying over the skin of the medial part of lower lid. Other eye was grossly within normal limits with visual acuity of 6/6 and N6.

A CT scan was performed which revealed globe luxation.(figure 2) A diagnosis of the left eye globe luxation with optic nerve avulsion was made and the patient was planned for globe repositioning. After explaining the procedure and the prognosis of the condition, an informed consent was obtained.

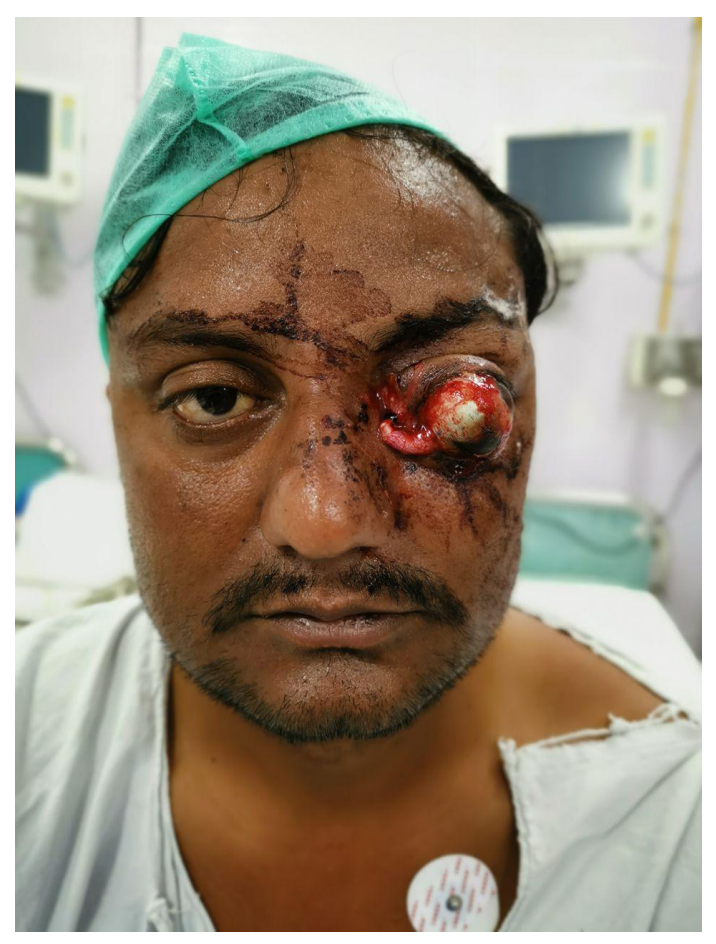

Figure 1 Preoperative clinical photograph showing globe luxation of the left eye with optic nerve head avulsion with medial canthal laceration.

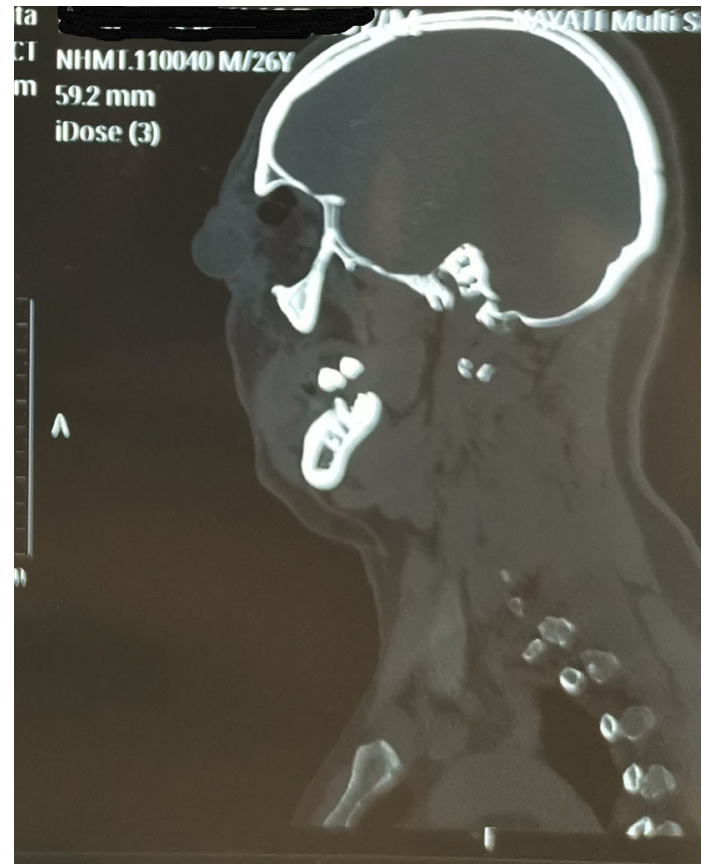

Figure 2 CT scan sagittal plane showing the globe completely outside the orbital rim.

The globe was then explored under aseptic condition under general anaesthesia for any perforations and none was found. The upper and lower lids were retracted and attempt was made to trace the medial rectus muscle, but was unsuccessful. Eyeball was gradually repositioned back into orbital cavity. Conjunctiva and tenon's were sutured back to globe. Medial lid and canthal laceration were repaired with 6-0 vicryl suture. Extensive canalicular injury was noted and so Mini-Monoka stent could not be placed. A temporary tarsorrhaphy was done. (figure 3) Postoperatively systemical and topical antibiotics and steroids were given. At 1 month follow-up the patient had left eye exotropia with hypertropia with no evidence of any necrosis or infection of the globe. (figure 4)

Globe luxation is a rare clinical condition in which eyeball protrudes out from orbital rim and appears caught between eyelid aperture, contraction of orbicularis oculi further add to anterior displacement of eyeball and maintains globe luxation. ${ }^{1}$ Cause for globe luxation can be traumatic, spontaneous or voluntary.

Spontaneous globe luxation is usually associated with predisposing factors like shallow orbit like Crouzon syndrome and floppy iris syndrome, lax supporting fascia and conditions causing severe proptosis like Graves' disease, histiocytosis X, orbital tumours and craniofacial dysostosis. ${ }^{2}$ 


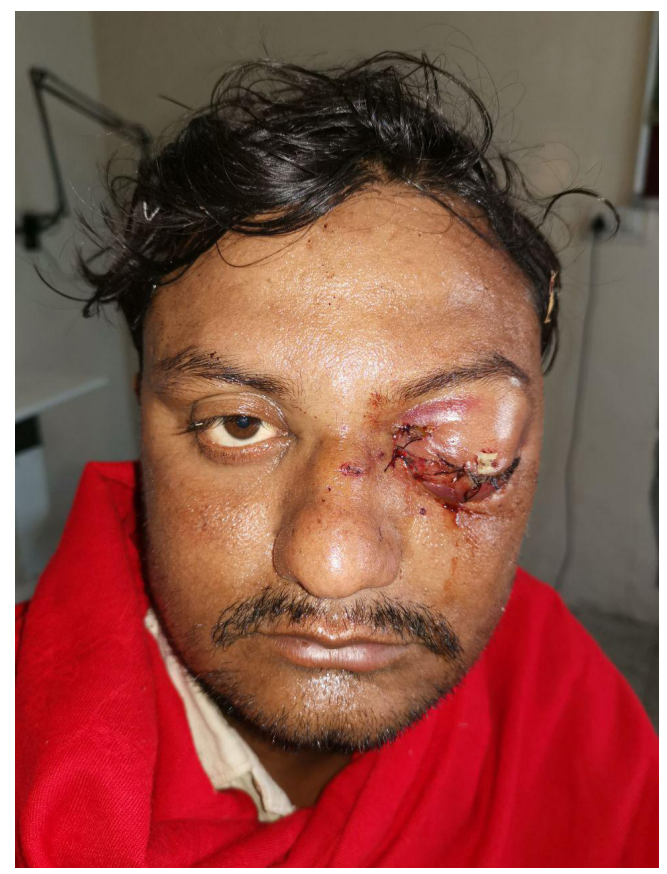

Figure 3 Postoperative clinical photograph showing reposited globe with temporary tarsorrhaphy in place.

Oedipism is a psychiatric condition where the patient enucleates his eyes. ${ }^{3}$

For traumatic globe luxation to occur it requires significant impact with high velocity to head and orbit and may be associated with avulsion of optic nerve, damage to extraocular muscles and fracture of orbit, facial bones and cranial vault. ${ }^{2}$ Cause of trauma can be road traffic accident, forceps delivery in obstructed labour or sports like gouging. In our case trauma was inflicted by cow's horn.

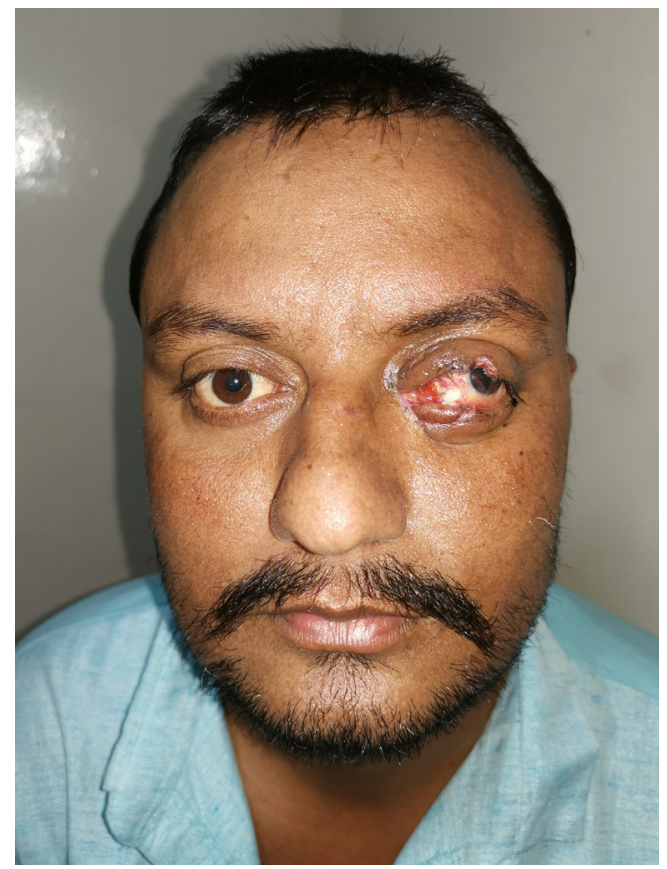

Figure 41 month after repostioning, globe healthy, hypertropic with exotropia.

\section{Patient's perspective}

I lost my eye in an accident. Life is very much uncertain.

\section{Learning points}

Luxation of globe is a surgical emergency and needs immediate attention.

- Early repositioning of luxated globe can reduce the chances of developing avascular damage to the globe.

Multiple mechanisms are described and combination of these take place leading to traumatic globe luxation. In cases of penetrating trauma, penetrating object enters orbit medially without disrupting globe anatomy causes forward displacement using nasal bridge as support. ${ }^{4}$ Also the penetrating object can damage extraocular muscles - medial rectus being in the way of object entry is the most common muscle to get injured. Depending on depth and angle of entry it can also cause avulsion of optic nerve fibres partially or completely.

In cases of blunt trauma, globe luxation can be due to orbit cavity becoming shallow following multiple orbit wall fractures leading to forward displacement of eyeball or a decelerating force on eyeball when sudden backward movement of head occurs. $^{2}$ In these cases optic nerve injury can be due to shearing forces as a result of globe rotation and forward displacement. ${ }^{5}$

Imaging studies can help to rule out complications like intracranial and subarachnoid haemorrhage and anterior and middle cranial fossa fracture. These patients are also at increased risk of orbital infection and meningitis and thus to be looked for during evaluation. $^{256}$

In traumatic cases management is primarily surgical and should be done as early as possible. Delay in surgery can cause compromised blood supply to intact optic nerve and oedema of lids, soft tissues and conjunctival chemosis making it difficult to reposition the globe. ${ }^{2}$

Surgery is performed to reposition the globe and explore for damage to extraocular muscles and repair if possible. ${ }^{5}$ Failure to repair extraocular muscles may lead to phthisis bulbi in future as the blood supply to globe is reduced. ${ }^{2}$ Enucleation is usually not the choice of surgery and attempt should be made to salvage and reposit the globe because the loss of globe not only gives psychological trauma to the patient but also reduces the chances of contracted socket formation in future.

Contributors RM, DD, RGK and SKM all were actively involved in diagnosis and management of the patient. Manuscript was prepared by DD and SKM.

Funding The authors have not declared a specific grant for this research from any funding agency in the public, commercial or not-for-profit sectors.

Competing interests None declared.

Patient consent for publication Obtained.

Provenance and peer review Not commissioned; externally peer reviewed.

\section{REFERENCES}

1 Reyniers R, Paridaens D. Spontaneous globe luxation and floppy eyelid syndrome in a patient with Hashimoto's disease. Eye 2007;21:303-4.

2 Bajaj MS, Kedar S, Sethi A, et al. Traumatic globe luxation with optic nerve transection. Orbit 2000;19:165-70

3 Jones NP. Self-enucleation and psychosis. Br J Ophthalmol 1990;74:571-3.

4. Tok L, Tok OY, Argun TC, et al. Bilateral traumatic globe luxation with optic nerve transection. Case Rep Ophthalmol 2014;5:429-34. 
5 Kumari E, Chakraborty S, Ray B. Traumatic globe luxation: a case report. Indian J Ophthalmol 2015:63:682-4.

6 Chang EL, Bernardino CR, Robert Bernardino C. Update on orbital trauma. Curr Opin Ophthalmol 2004;15:411-5.

Copyright 2019 BMJ Publishing Group. All rights reserved. For permission to reuse any of this content visit https://www.bmj.com/company/products-services/rights-and-licensing/permissions/

BMJ Case Report Fellows may re-use this article for personal use and teaching without any further permission.

Become a Fellow of BMJ Case Reports today and you can:

- Submit as many cases as you like

- Enjoy fast sympathetic peer review and rapid publication of accepted articles

- Access all the published articles

Re-use any of the published material for personal use and teaching without further permission

For information on Institutional Fellowships contact consortiasales@bmjgroup.com

Visit casereports.bmj.com for more articles like this and to become a Fellow
7 Gupta RC, Gupta P. Complete globe protrusion post trauma: A case report. ISOR J Dent Med Sci 2013:6:28-9. 